\title{
PROFIL PENDUDUK KABUPATEN CIANJUR
}

\author{
Nunung Nurwati, dan Nandang Mulyana
}

nng.nurwati@yahoo.com, mulayana.nandang@yahoo.com

\begin{abstract}
ABSTRAK
Informasi tentang kependudukan memiliki peran yang penting dalam penyusunan program pembangunan, oleh karena itu penduduk tidak saja sebagai objek pembangunan tetapi sebagai subjek, artinya penduduk tidak hanya menikmati pembangunan tetapi juga yang menggerakkannya.Sehingga penyusunan program pembangunan harus didasarkan pada data atau informasi tentang karakteristik penduduk di suatu walayah dalam waktu tertentu. Untuk itu, kajian ini tujuan menyusun profil kependudukan.

Metode yang digunakan dalam kajian ini dengan pendekatan kualitatif. Data yang digunakan bersumber dari data hasil publikasi yakni Data Sensus Penduduk tahun 2010, Sensus Demografi dan Kesehatan Indonesia (SDKI) tahun 2012, Survey Sosial Ekonomi Nasional (Susenas), Survey Sosial Ekonomi Daerah (Suseda).Kajian ini dilakukan di Kabupaten Cianjur Jawa Barat.

Hasil kajian ini menemukan bahwa tingkat kepadatan penduduk di daerah penelitian tidak merata. Tertinggi ada di Kecamatan Cianjur, Pacet, Cegenang, dan Cipanas. Wilayah ini merupakan kecamatan yang menjadi tujuan wisata, sehingga banyak menarik penduduk dari luar daerah untuk mendatanginya.Gambaran ini akan menjadi informasi awal tentang kependudukan bagi pembuat kebijakan.
\end{abstract}

Kata kunci: Profil kependudukan. Kabupaten Cianjur. Jawa Barat

\begin{abstract}
Information on population has an important role in the development programming, therefore the population is not only the object of development but as the subject, meaning that the people not only enjoy the development but also who mobilize it. So the development program should be based on data or information about the characteristics of the population in a walayah within a certain time. For this purpose, this study aims to develop a population profile.

The method used in this study with a qualitative approach. The data used are from data of publication result that is 2010 Population Census Data, Indonesian Demographic and Health Census (SDKI) 2012, National Socioeconomic Survey (Susenas), Survey of Socio-Economic Area (Suseda). This study was conducted in Cianjur Regency, West Java

The results of this study found that the population density in the study area was uneven. The highest is in District Cianjur, Pacet, Cegenang, and Cipanas. This region is a sub-district that became a tourist destination, so much to attract residents from outside the region to visit him. This picture will be the initial information about the population for policy makers.
\end{abstract}

Key Word : Population Profile. Regency of Cianjur. West Java

\section{PENDAHULUAN}

Penyusunan program pembangunan pada hakekatnya tidak terlepas dari aspek kependudukan. Kondisi disebabkan karena penduduk merupakan komponen penting dalam pembangunan. Penduduk dalam program pembangunan memiliki dua pandangan yaitu sebagai subyek pembangunan dan sebagai obyek pembangunan. Sebagai subyek pembangunan, penduduk merupakan komponen yang menggerakkan pembangunan itu sendiri. Sedangkan sebagai obyek pembangunan penduduk merupakan komponen yang menikmati hasil dari pembangunan. Jadi penduduk dalam program pembangunan merupakan pelaksana dan menikmat hasil dari pembangunan. 
Berdasarkan pendangan tersebut program pembangunan yang dilaksanakan harus mengacu kepada kondisi kependudukan dari suatu wilayah.

Jawa Barat sebagai propinsi terdepan dan merupakan propinsi penyangga ibukota tentunya tidak terlepas dari masalah kependudukan. Hasil sensus 2010 memperlihatkan bahwa jumlah penduduk Propinsi Jawa Barat merupakan jumlah yang terbesar se-Indonesia yakni berjumlah 43,05 juta jiwa. Laju pertambahan penduduk di Propinsi Jawa Barat juga relative tinggi yaitu 1,89\% pertahun. Angka laju pertumbuhan ini sebenarnya menunjukkan penurunan setiap sensus dilakukan. Pada sensus 1990 laju pertumbuhan penduduk 2,3\%, sensus 2000 sebesar $2,93 \%$. Besarnya jumlah penduduk tersebut tidak serta merta diiringi dengan kualitas yang baik dan persebaran yang seimbang. Pertumbuhan penduduk serta kualitas dan sebaran tersebut harus dicermati oleh semua pihak, serta diperlukan adanya kebijakan kependudukan yang terintegrasi dan berkelanjutan dalam menopang pengendalian penduduk. Hal ini perlu dilakukan karena dengan tingkat pertumbuhan yang relatif tinggi akan mengancam terhambatnya pembangunan di Jawa Barat.

Permasalahan penduduk di Jawa Barat juga berimbas pada Kabupaten Cianjur. Hasil sensus 2010 menunjukkan jumah penduduk di Kabupaten Cianjur sebesar 2.171.281 jiwa. Laju pertumbuhan penduduk di Kabupaten Cianjur sebesar 1,11\%. Dilihat dari laju pertumbuhan penduduk, Kabupaten Cianjur lebih kecil dibandingkan dengan laku pertumbuhan Propinsi Jawa Barat. Akan tetapi jika dilihat dari angka fertilitas, kabupaten Cianjur menempati urutan kedua di Jawa Barat setelah Kabupaten Garut. Angka fertilitas Kabupaten Cianjur rata-rata jumlah anak 2,8 perwanita lebih tinggi dari Propinsi Jawa Barat sebesar 2,5 perwanita. Ini artinya setiap wanita penduduk Kabipaten
Cianjur rata-rata melahirkan tiga anak selama hidupnya. Angka ini melebihi dari keinginan pemerintah dalam hal ini BKKBN yang menginginkan hanya dua anak perwanita. Angka ini dimasa akan datang akan menjadi potensi bagi Kabupaten Cianjur terjadi ledakan penduduk.

Disisi lain permasalahan penduduk di Kabupaten Cianjur adalah rasio penduduk antara laki-laki dengan perempuan. Rasio penduduk di Kabupaten Cianjur mencapai 107,15. Artinya setiap 100 penduduk perempuan ada lebih dari 107 penduduk lakilaki. Angka rasio ini kurang ideal karena angka ideal suatu rasio penduduk berada di kisaran 98-102. Hal ini disebabkan karena Kabupaten Cianjur merupakan salah satu tujuan wisata di Propinsi Jawa Barat yaitu daerah Puncak. Demikian juga dengan sebaran penduduk. Dengan daerah yang luas sebaran penduduk di Kabupaten Cianjur cukup kecil hanya 604 jiwa perkm persegi. Dengan sebaran tersebut serta luasnya wilayah dan distribusi yang kurang merata yang disebabkan karena perbedaan daya tarik wilayah yang berimbas pada ketersediaan lapangan pekerjaan, kenis pekerjaan, sarana dan prasara akan mendorong perbedaan karakteristik penduduk di Kabupaten Cianjur.

Perbedaan karakteristik penduduk yang ada di Kabupaten Cianjur perlu dipahami oleh semua pihak. Pemahaman ini berguna untuk membuat kebijakan kependudukan dalam rangka pengendalian dan penanggukangan dampak dari pertumbuhan penduduk yang tinggi. Pemahaman karakteristik penduduk ini tidak terlepas dari data kependudukan yang ada. Data kependudukan ini menjadi penting karena dapat dijadikan dasar dan mempengaruhi kebijakan pengendalian penduduk. Kebenaran dan akurasi data kependudukan ini menjadi penting karena akan berpengaruh terjadap kebijakn yang akan diambil. Data yang benar dan akurat 
akan mendorong kebijakan yang sesuai dengan karakteristik dan kebutuhan penduduk. Demikian juga sebaliknya jika data kurang baik dan kurang akurat maka kebijakan yang diambil tidak akan sesuai dengan kebutuhan penduduk itu sendiri. Jadi untuk membuat kebijakan pengendalian kependudukan yang sesuai dengan kebutuhan penduduk diperlukan adanya profil kependudukan di Kabupaten Cianjur. Penyediaan data kependudukan diperlukan dalam pemahaman menyeluruh terhadap stakeholders pada khususnya dan masyarakat pada umumnya serta dalam rangka menyusun kebijakan kependudukan.

Kajian ini mempunyai dua tujuan yaitu tujuan umum dan tujuan khusus. Tujuan umum dari kajian dan analisis penduduk Kabupaten Cianjur adalah mengetahui karakteristik kependudukan Kabupaten Cianjur.

\section{METODE}

Metode yang digunakan dalam kajian ini menggunakan pendekatan kualitatif. Data yang digunakan berasal dari data sekunder, yakni yang bersumber dari Data Sensus Penduduk tahun 2010, Sensus Demografi dan Kesehatan Indonesia (SDKI) tahun 2012, Survey Sosial Ekonomi Nasional (Susenas), Survey Sosial Ekonomi Daerah (Suseda), serta data yang bersumber dari dinas-dinas dan instansi terkait sesuai dengan kebutuhan.

\section{PEMBAHASAN}

Kondisi geografis Wilayah Kab. Cianjur terdiri dari 3 karakterisitk, yang pertama adalah wilayah Utara yang didominasi wilayah pegunungan dengan kondisi udara sejuk wilayah ini berkembang menjadi wilayah industri pariwisata dan tentunya diikuti juga oleh pusat-pusat pertumbuhan seperti di wilayah Cipanas dan sekitarnya. Kedua adalah Cianjur bagian Tengah, dengan kondisi geografis lahan/dataran rendah dengan berbukit-bukit, umumnya wilayah tengah ini perkembangan lebih pada sektor pertanian, sebagai pusat pemerintahan dan saat ini mulai ada industri yang berdiri di wilayah tengah Cianjur, terakhir adalah wilayah Selatan, dengan karakteristik wilayah dataran rendah, dengan berbukit-bukit, selain pertanian, penduduk umumnya bermatapencaharaian sebagai nelayan, dan potensi wilayah selatan ini dapat juga dikembangkan untuk sektor wisata bahari.

Jumlah penduduk Kabupaten Cianjur menurut hasil Sensus Penduduk tahun 2010 adalah sebesar 3.116.867 jiwa yang terdiri dari 1.614.307 laki-laki dan 1.505.560 perempuan dan tersebar di tiga puluh dua kecamatan, sementara itu rasio jenis kelamin Kabupaten Cianjur yaitu 95,26 \% yang berarti setiap 100 perempuan terdapat 107 orang laki-laki. Jumlah penduduk tersebut tersebar di tiga wilayah Cianjur yang memiliki luas total sebesar $13.595 .02 \mathrm{~km} 2$. 
Tabel 1

Jumlah Penduduk Berdasarkan Luas Wilayah di Kecamatan di Tiga Wilayah Cianjur

\begin{tabular}{|c|c|c|c|c|c|c|c|c|}
\hline \multicolumn{3}{|c|}{ Cianjur Utara } & \multicolumn{3}{|c|}{ Cianjur Tengah } & \multicolumn{3}{|c|}{ Cianjur Selatan } \\
\hline Kecamatan & $\begin{array}{c}\text { Luas } \\
\text { Wil } \\
\end{array}$ & $\begin{array}{l}\text { Jml } \\
\text { Pend }\end{array}$ & Kecamatan & $\begin{array}{c}\text { Luas } \\
\text { Wil }\end{array}$ & $\begin{array}{c}\text { Jml } \\
\text { Pend }\end{array}$ & Kecamatan & $\begin{array}{c}\text { Luas } \\
\text { Wil }\end{array}$ & $\begin{array}{c}\text { Jml } \\
\text { Pend }\end{array}$ \\
\hline Cibeber & 130,96 & 184,757 & Tanggeung & 114,15 & 61,825 & Agrabinta & 200,67 & 60,121 \\
\hline Warungkondang & 48,75 & 102,180 & Pasirkuda & - & 49,285 & Leles & 94,10 & 42,495 \\
\hline Gekbrong & 46,50 & 72,691 & Pagelaran & 235,50 & 97,618 & Sindangbarang & 167,95 & 77,972 \\
\hline Cilaku & 60,46 & 152,655 & Kadupandak & 104,79 & 65,463 & Cidaun & 320,72 & 112,148 \\
\hline Sukaluyu & 43,10 & 90,526 & Cijati & 49,81 & 45,365 & Naringgul & 243,78 & 60,162 \\
\hline Bojongpicung & 123,53 & 92.942 & Takokak & 135,76 & 64,972 & Cibinong & 225,33 & 82,736 \\
\hline Haurwangi & - & 82,763 & Sukanagara & 164,84 & 62,636 & Cikadu & 173,09 & 59,465 \\
\hline Ciranjang & 37,52 & 104.080 & Campaka & 135,47 & 85.626 & & & \\
\hline Mande & 105,11 & 89,337 & Campakamulya & 59,96 & 32,795 & & & \\
\hline Karangtengah & 39,25 & 162.637 & & & & & & \\
\hline Cianjur & 23,44 & 214,609 & & & & & & \\
\hline Cugenang & 65,37 & 143,178 & & & & & & \\
\hline Pacet & 54,11 & 133,639 & & & & & & \\
\hline Cipanas & 58,03 & 162,161 & & & & & & \\
\hline Sukaresmi & 113,31 & 134,889 & & & & & & \\
\hline Cikalongkulon & 126,02 & 136,141 & & & & & & \\
\hline
\end{tabular}

Sumber Data: Cianjur Dalam Angka Tahun 2013

Jumlah penduduk paling banyak terdapat di Kecamatan Cianjur, yaitu sebanyak 214,609 jiwa. Selain itu, Kecamatan Cianjur juga menjadi kecamatan yang terpadat. Dimana, 214,609 jiwa menempati wilayah kecamatan yang hanya seluas 23,44 ha. Kondisi ini lebih banyak disebabkan karena Kecamatan Cianjur merupakan pusat kota dari Kabupaten Cianjur. Kegiatan perekonomian Kabupaten Cianjur terpusat di Kecamatan Cianjur, sehingga banyak menarik penduduk dari luar Kecamatan Cianjur untuk datang dan menetap di Kecamatan Cianjur. Selain itu juga di Wilayah Cianjur Utara kecamatan Pacet, Cegenang, dan Cipanas juga memperlihatkan tingkat kepadatan penduduk yang tinggi. Ketiga kecamatan tersebut merupakan kecamatan yang menjadi tujuan wisata untuk Kabupaten Cianjur. Dengan demikian banyak menarik penduduk dari luar daerah.

Kondisi padatnya penduduk yang berada di wilayah Cianjur Utara tersebut sangat dimungkinkan terjadi, seperti yang telah di uraikan sebelumnya bahwa wilayah Cianjur Utara telah berkembang menjadi kawasan industri wisata yang sangat terkenal, bahkan pada tiap akhir pekan kawasana ini akan dpenuhi pengunjung dari berbagai wilayah, tidak hanya dari sekitar Jawa Barat, namun pengungjung banyak berdatangan dari wilayah DKI Jakarta dan Provinsi Banten, dan wilayah lainnya. Kondisi inilah yang kemudian menjadi 'magnet' atau faktor daya tarik seseorang untuk tinggal di wilayah tersebut, menurut data dari Statistik Daerah Kabupaten Cianjur Tahun 2012, di sebutkan bahwa ternyata wilayah Kab. Cianjur tidak hanya menjadi tujuan wisata bagi wisatawan domestik, namun sudah menjadi tujuan 
wisata juga bagi wisatawan luar negeri, dicatat pula dalam Statistik Daerah Kabupaten Cianjur Tahun 2012 bahwa wisatawan domestik mencapai 864.789 jiwa yang berkunjung ke Kab. Cianjur, sementara itu kunjungan wisatawan luar negeri mencapai 3.190 jiwa. Hal ini menunjukan bahwa wilayah Cianjur Utara, khususnya kawasana wisata akan terus berpotensi di datangi oleh penduduk tidak hanya sebagai wisatawan namun juga sebagai pencari nafkah, sehingga hal ini perlu disikapi dengan cermat, pemda sudah saatnya menata dan mengelola secara menyeluruh kawasan wisata tersebut sehingga dampak-dampak akibat perkembangan/pertumbuhan wilayah dapat diminimalkan. Sebab bukan tidak mungkin pertumbuhan dan perkembangan kawasan wisata bukan hanya memberikan nilai positif namun dapat juga berdampak negatif terutama pada aspek kelestarian lingkungan

Hal tersebut bertolak belakang dengan kecamatan-kecamatan lainnya yang berada di Wilayah Cianjur Selatan seperti wilayah Kecamatan Cidaun yang memiliki wilayah paling luas, yaitu 320,72 ha dan memiliki penduduk sebanyak 112,148 jiwa. Wilayah Cianjur Selatan relatif sangat luas, sedangkan jumlah penduduk relatif sedikit. Hal ini disebabkan wilayah Cianjur Selatan merupakan wilayah pertanian dan pantai yang masih belum dikembangkan secara maksimal. Dengan demikian selain masyarakatnya sedikit juga banyak penduduk yang keluar daerah Cianjur Selatan untuk bekerja atau melanjutkan pendidikan.

Terkait dengan kondisi kependudukan di Kabupaten Cianjur, dapat dilihat pula data mengenai persentase penduduk berdasarkan jenis kelamin dan status perkawinan. Data tersebut akan dapat memberikan gambaran secara umum mengenai isu-isu kependudukan yang muncul di Kabupaten Cianjur. Berikut tabel yang menunjukkan persentase jenis kelamin dengan status perkawinan di Kabupaten Cianjur.

Tabel 2

Persentase Penduduk Berdasarkan Jenis Kelamin dan Status Perkawinan

\begin{tabular}{|l|c|c|c|}
\hline \multirow{2}{*}{$\begin{array}{c}\text { Status } \\
\text { Perkawinan }\end{array}$} & \multicolumn{2}{|c|}{ Jenis Kelamin } & \multirow{2}{*}{ Jumlah } \\
\cline { 2 - 3 } \multicolumn{1}{c|}{$(\mathbf{1})$} & $\mathbf{L}$ & $\mathbf{P}$ & \\
\hline Belum Kawin & 49,34 & $\mathbf{( 3 )}$ & $\mathbf{( 4 )}$ \\
\hline Kawin & 47,42 & 49,07 & 45,64 \\
\hline Cerai Hidup & 1,72 & 3,22 & 48,22 \\
\hline Cerai Mati & 1,52 & 5,99 & 3,70 \\
\hline Total & $\mathbf{1 0 0}$ & $\mathbf{1 0 0}$ & $\mathbf{1 0 0}$ \\
\hline
\end{tabular}

Sumber Data: Cianjur Dalam Angka Tahun 2013

Merujuk pada data tersebut, secara umum ternyata bahwa sebagian besar dari penduduk Kab. Cianjur berstatus kawin/menikah, berdasarkan data dari Hasil Pendataan Keluarga Kab. Cianjur Tahun 2012 (Badan Keluarga Berencana dan Pemberdayaan Perempuan Kab. Cainjur) tercatat bahwa sekitar 553.682 Pasangan Usia Subur (PUS) atau sekitar 81,79 \% dari jumlah Kepala Keluarga (KK) di Kab. Cianjur. Dengan mencermati data-data tersebut maka nampaknya PUS yang dikategorikan oleh BKBPP Kab. Cianjur sebagai resiko tinggi perlu mendapatkan perhatian khusus terutama dalam programprogram penyelenggaraan Keluarga Berencana $(\mathrm{KB})$ ataupun program lainnya yang bertujuan mengendalikan pertumbuhan pendudukan, sebab PUS di Kab. Cianjur ini mendominasi dari segi kuantitas dan bukan hal yang mustahil bila dikemudian hari akan terjadi ledakana penduduk akibat angka kelahiran atau fertilitas yang kurang dikendalikan. Selain status perkawinan, dapat pula dilihat sebaran penduduk berdasarkan jenis kelamin di kecamatan di tiga wilayah Cianjur. Berikut tabel yang menggambarkan sebaran penduduk berdasarkan jenis kelamin. 
Selain sebaran jumlah penduduk, berdasarkan hasil Susenas tahun 2011 penduduk usia 15 tahun ke atas yang merupakan angkatan kerja yaitu 960.544 jiwa yang terdiri dari laki-laki sebanyak 659.920 jiwa dan perempuan sebanyak 300.624 jiwa. Angkatan kerja yang bergerak di sektor pertanian, kehutanan, perburuan dan perikanan mencapai 40,50 persen, industri 5,26 persen, perdagangan, rumah makan dan hotel 21,09 persen, jasa kemasyarakatan 14,75 persen, dan lainnya meliputi pertambangan dan penggalian, listrik, gas dan air, bangunan, angkutan, pergudangan dan komunikasi, keuangan, asuransi, persewaan dan jasa perusahaan mencapai 17,59 persen. Dengan demikian sektor pertanian merupakan sektor terbesar disusul dengan sektor perdagangan hal ini merupakan suatu ukuran untuk melihat potensi setiap sektor perekonomian di Kabupaten Cianjur.

Pentingnya memahami isu-isu kependudukan dalam pembangunan adalah karena masalah kependudukan dapat menjadi faktor penyebab dari masalah-masalah sosial lainnya. Tingginya angka kelahiran akan mempengaruhi ketersediaan lapangan kerja, dan secara tidak langsung dapat menyebabkan tingginya angka kriminalitas. Selain itu, tingginya angka kelahiran juga akan mempengaruhi ketersediaan pangan.

Dengan memahami akan pentingnya isu kependudukan dalam pembangunan, maka antara pemerintah daerah dan pemerintah pusat akan terjalin kerjasama yang baik dan proses pelayanan akan lebih terintegrasi. Seperti misalnya dalam hal pendataan keluarga, tidak semua instansi memiliki data mengenai gender, akan tetapi data tersebut dapat diakses dari instansi lain yang memiliki sumber data terkait. Contoh lainnya seperti pembangunan di bidang kesehatan yang tidak bisa dilepaskan dengan isu mortalitas yang berpengaruh kepada kependudukan. Dengan kata lain, pembangunan kesehatan tidak bisa berdiri sendirian. Terkait dengan keberhasilan pembangunan di Kabupaten Cianjur, dapat dilihat dari angka Indeks Prestasi Manusia (IPM).

Tabel 3

Angka IPM Kab. Cianjur dan Provinsi Jawa Barat untuk Tahun 2008 - 2012

\begin{tabular}{|l|c|c|c|c|c|c|c|c|c|r|}
\hline \multicolumn{1}{|c|}{ Variabel IPM } & \multicolumn{2}{c|}{$\mathbf{2 0 0 8}$} & \multicolumn{2}{c|}{$\mathbf{2 0 0 9}$} & \multicolumn{2}{c|}{$\mathbf{2 0 1 0}$} & \multicolumn{2}{c|}{2011} & \multicolumn{2}{c|}{2012} \\
\hline (poin) & Kab & Jabar & Kab & Jabar & Kab & Jabar & Kab & Jabar & Kab & Jabar \\
\hline IPM & 68,16 & 71,12 & 68,66 & 71,64 & 69,14 & 72,29 & 69,59 & 72,73 & 70,02 & 73,11 \\
\hline Indeks Pendidikan & 79,07 & 80,35 & 79,55 & 81,14 & 80,62 & 81,67 & 80,62 & 82,55 & 80,38 & 82,75 \\
\hline AMH & 97,21 & 95,53 & 97,45 & 95,98 & 97,55 & 96,00 & 97,64 & 96,29 & 97,67 & 96,39 \\
\hline Indeks Kesehatan & 67,15 & 71,33 & 67,74 & 71,67 & 68,33 & 72,00 & 68,91 & 72,34 & 69,50 & 72,67 \\
\hline AHH & 65,29 & 67,80 & 65,64 & 68,00 & 66,00 & 68,20 & 66,35 & 68,40 & 66,70 & 68,6 \\
\hline Indeks Daya Beli & 58,26 & 61,66 & 58,53 & 62,10 & 58,89 & 62,57 & 59,53 & 63,57 & 60,18 & 64,17 \\
\hline
\end{tabular}

Sumber: BPS Provinsi Jawa Barat, 2012 
Berdasarkan angka pada tabel 3, terlihat Kabupaten Cianjur berada pada nomor urut dua puluh tiga dari dua puluh lima Kabupaten/Kota di Jawa Barat. Hal tersebut tidak lepas dari permasalahan yang dihadapi dalam bidang kependudukan. Saat ini, pemerintah daerah Kabupaten Cianjur melalui Dinas Kependudukan Kabupaten CIanjur sedang merumuskan formula yang tepat untuk mengatasi masalah kependudukan. Salah satu upaya yang dilakukan adalah melakukan verifikasi data kependudukan. Jumlah penduduk Kabupaten Cianjur yang tercatat adalah sekitar 2.300.000 jiwa, namun jumlah tersebut berbeda dengan data yang ada di Dinas Kependudukan. Dinas Kependudukan mencatat jumlah penduduk Kabupaten Cianjur mencapai sekitar 3.100.000 jiwa. Perbedaan jumlah tersebut dicurigai karena adanya kasus kartu penduduk ganda, sehingga menyebabkan kekeliruan dalam penghitungan jumlah penduduk. Kasus-kasus seperti ini seharusnya tidak boleh terjadi, karena akan mempengaruhi jalannya pembangunan di Kabupaten Cianjur

\section{SIMPULAN}

1. Kondisi geografis Kab. Cianjur yang berbeda antara wilayah Utara, tengah dan Selatan telah memberikan andil dalam keragaman matapencaharaian penduduknya, sebagai contoh penduduk yang ada di wilaya utara Cianjur umumnya bekerja pada sektor pertanian dan jasa, hal ini berbeda dengan wilayah selatan Cianjur, selain bertani penduduk juga umumnya bermatapencaharaian sebagai nelayan.

2. Jumlah penduduk terbanyak dan terpadat ada di Kecamatan Cianjur, Pacet, Cegenang, dan Cipanas juga memperlihatkan tingkat kepadatan penduduk yang tinggi. Wilayah ini merupakan kecamatan yang menjadi tujuan wisata untuk Kabupaten Cianjur. Dengan demikian banyak menarik penduduk dari luar daerah.

\section{DAFTAR PUSTAKA}

Badan Pusat Statistik.2012. Sensus Penduduk Jawa Barat. 2012. Bandung

Badan Pusat Statistik. 2014. Kabupaten Cianjur Dalam Angka Tahun 2013. Cianjur.

Badang Pusat Statistik. 2014. Survey Demografi Dan Kesehatan Indonesia Tahun 2013. Bandung.

Bappeda. 2014. Rencana Pembangunan Jangka Panjang kabupaten Cianjur Tahun 2013. Cianjur. 